\title{
Deskripsi keterampilan proses sains mahasiswa pendidikan fisika pada praktikum suhu dan kalor
}

\author{
Darmaji, Dwi Agus Kurniawan, dan Ayu Lestari \\ Program Studi Pendidikan Fisika, FKIP Universitas Jambi \\ J1. Lintas Jambi - Muara Bulian Km. I5, Mendalo Darat, Jambi Luar Kota, Kota Jambi, Jambi 36122 \\ Surat-e: Darmaji@unja.ac.id
}

Penelitian dilakukan untuk mendeskripsikan keterampilan proses sains mahasiswa pendidikan fisika Universitas Jambi setelah menggunakan penuntun praktikum Fisika Dasar II berbasis Keterampilan Proses Sains ada percobaan suhu dan kalor. Penelitian ini jenis kuantitatif. Penelitian ini mahasiswa yang diikutsertakan yaitu 9I orang. Lembar observasi keterampilan proses sains digunakan mengumpulkan data dan diperkuat dengan wawancara serta dokumentasi. Data dianalisis dengan statistik deskriptif. Hasil analisis memperlihatkan jika Keterampilan Proses Sains yang dapat dikuasai mahasiswa yaitu mengukur dan eksperimen. Hasil penelitian diharapkan menjadi pertimbangan bagi program studi fisika untuk melakukan studi terkait untuk mata kuliah praktikum lainnya.

The research was conducted to find out the description about science process skill of physics education student of Jambi University on an experiment of temperature and heat. The research is quantitative research with the quasi-experimental method. This research takes 9I students as sample. Observation sheets are used to collect data and reinforced by interviews and documentation. Data were analyzed with descriptive statistics. The results of the analysis show that SPS that can be mastered by students is measuring and experimenting. The result of the study is expected to be the consideration to program and other faculties at Jambi University and other Universities to conduct related studies.

Kata kunci: Keterampilan Proses Sains, Pendidikan Tinggi, Suhu dan Kalor.

\section{Pendahuluan}

Di samping aspek kognitif dan afektif, keterampilan merupakan bagian vital yang harus dimiliki oleh seorang mahasiswa. Lulusan dengan pengetahuan yang tinggi dan ditunjang keterampilan yang baik tentu sangat dibutuhkan di dunia kerja dibandingkan dengan lulusan yang hanya memiliki pengetahuan tanpa dibekali keterampilan yang menyelaraskannya. Bagi seorang mahasiswa pendidikan fisika, keterampilan yang perlu untuk dimiliki salah satunya adalah Katerampilan Proses Sains. Proses kegiatan ilmiah diperlukan suatu keterampilan dalam bidang sains yang dapat disebut keterampilan proses sains [3]. Keterampilan proses sains diperlukan untuk menunjang teori pembelajaran melalui perecobaan. Menurut Ref. [4], KPS berhubungan terhadap percobaan dari hasil pemahaman konseptual dan penerapan sains. Menurut Ref. [5] menyatakan bahwa, seorang guru sangat penting memiliki pemahaman keterampilan proses sains, dikarenakan dapat membantu ketika penyelidikan dan membangun konsep sains. Berdasarkan latar belakang dan kajian teori terhadap pentingnya KPS bagi seorang calon guru maka penelitian dilakukan untuk mengetahui kemampuan KPS mahasiswa pendidikan fisika di Universitas Jambi tahun 2017 melalui praktikum materi suhu dan kalor di Universitas Jambi tahun 2017.

\section{Kajian Pustaka}

Pembelajaran fisika terkhusus materi suhu dan kalor merupakan pembelajaran yang tidak hanya membahas teori dari para ilmuwan, melainkan juga melakukan praktikum untuk memperjelas teori yang diterima. Menurut Ref. [6] menyatakan bahwa, matakuliah praktikum menolong untuk meningkatkan pemahaman teori maupun konsep yang telah diterimanya. Dalam kegiatan praktikum, selain mengembangkan psikomotorik, juga dapat mengembangkan keterampilan 
Deskripsi keterampilan proses sains mahasiswa pendidikan fisika pada praktikum suhu dan kalor

afektif dan kognitif [7]. Dengan demikian KPS baik dimiliki mahasiswa pendidikan fisika karena dapat membantu mengelola pengetahuan melalui informasi dari proses praktikum.

Keterampilan proses sains diklasifikasikan dalam dua kategori. Kategoti tersebut menurut Ref. [4] yaitu keterampilan proses sains dasar dan terpadu. KPS ketegori dasar, Ref. [8] meliputi indikator mengamati, membandingkan, mengelompokkan, menimbang, memprediksi, mendefinisikan secara operasional, mengukur, mencatat dan menafsirkan, merumuskan model, tabel data dan grafik. Indikator KPS terpadu menurut Ref. [9] meliputi identifikasi variabel, data tabulasi, definisi variabel, pembuatan hipotesis, analisis investigasi, perancangan investigasi, percobaan, dan menggambarkan grafik. Pada periode prasekolah keterampilan proses sains kategori dasar telah dapat diperoleh [IO]. Menurut Ref. [II] keterampilan proses sains kategori terpadu, diperoleh sejak peserta didik pada kelas menengah atau pada kelas 5 hingga kelas 8 . Menurut Ref. [I2] menyatakan jika KPS dasar adalah prasyarat untuk memahami KPS terpadu.

Keterampilan proses sains dasar dan terpadu sangat dibutuhkan bagi calon guru fisika, karena selain dapat membantu ketika penyelidikan ilmiah, keterampilan ini juga berguna ketika proses mengajar. KPS mutlak harus dipunyai oleh seorang guru [I3]. Diketahui dari hasil penelitian, bila seorang guru dengan KPS maka guru dapat mengembangkan dan mengajarkan KPS di kelas dengan aktif [14]. Ref. [15] mendefinisikan bahwa keterampilan proses sains merupakan suatu keterampilan yang memberikan sarana dalam pembelajaran sains, penelitian dan pembelajaran yang aktif, membangun rasa bertanggungjawab saat pembelajaran dan meningkatkan pengetahuan. Apabila seorang guru tidak memiliki KPS maka guru akan sulit menumbuhkan KPS dalam diri peserta didik, kegiatan pembelajaran dikelas menjadi pasif dan monoton. Dampaknya peserta didik akan sulit mengembangkan serta mengintegrasikan pengetahuan secara mandiri. Guru dengan pemahaman KPS rendah akan memiliki kemampuan rendah pada penggunaan inkuiri dan strategi pengajaran lainnya di kelas [16].

\section{Metode Penelitian}

Penelitian ini merupakan penelitian kuantitatif metode Quasi-Eksperiment dengan model Posttest-Only Control Group Design. Menurut Ref. [I7], desain penelitian eksperimental kuasi dilakukan dengan memanipulasi variabel independen dan untuk kelompok perlakuan tidak dipilih secara acak. Penelitian mengambil sampel 9I orang mahasiswa pendidikan fisika Universitas Jambi tahun 2017. Pada penelitian ini, sampel yang digunakan kurang dari I00 orang, menurut Ref. [I8] teknik pengambilan data yang cocok yaitu teknik total sampling.

Teknik pengambilan data melalui lembar observasi ketika mengamati keterampilan proses sains (KPS) mahasiswa selama praktikum. Lembar observasi efektif dipakai untuk mengukur KPS [19]. Lembar observasi berpedoman pada indikator mengukur, prediksi, membuat hipotesis, dan eksperimen. Wawancara dilakukan untuk memperkuat data analisis kuantitatif lembar observasi.

Data Keterampilan Proses Sains mahasiswa dianalisis dengan statistik descriptif. Kemudian untuk mengetahui penguasaan KPS oleh mahasiswa akan dikelompokan kedalam 4 skala, seperti pada tabel I.

Tabel I. Skala penguasaan KPS mahasiswa

\begin{tabular}{ccc}
\hline No & Interval & Kategori \\
\hline I & $25,00-43.75$ & Sangat tidak baik \\
2 & $43.76-62.5$ & Tidak baik \\
3 & $62.5 \mathrm{I}-81.25$ & Baik \\
4 & $81.26-100,00$ & Sangat baik \\
\hline
\end{tabular}

\section{Hasil Penelitian dan Pembahasan}

\section{Hasil}

Berdasarkan analisis yang dilakukan, penuntun praktikum berbasis (KPS) rata-rata membuat KPS mahasiswa meningkat pada beberapa indikator KPS dasar dan KPS terpadu walaupun ada beberapa KPS yang masih belum dapat ditingkatkan seperti pada indikator membuat prediksi serta hipotesis. Berikut hasil analisis deskriptif KPS mahasiswa pada percobaan suhu dan kalor pada kegiatan Perubahan Wujud (PW), Kalorimeter (KAL), Kalor Jenis Cairan (KJC), dan Kalor Lebur Es (KLE) diperlihatkan pada tabel 2.

Tabel 2. Hasil Analisis Keterampilan Proses Sains Mahasiswa Pada Materi Suhu dan Kalor

\begin{tabular}{cccc}
\hline Kegiatan & KPS & Mean & Std. Deviasi \\
\hline PW & Mengukur & 77,8389 & I4,71020 \\
& Prediksi & 83,7912 & 18,39898 \\
& Hipotesis & 64,8352 & 25,27021 \\
& Eksperimen & 79,5791 & II,52I42 \\
KAL & Mengukur & 67,7397 & 16,08185 \\
& Prediksi & 67,0330 & 24,96640 \\
& Hipotesis & 65,1099 & 23,23764 \\
& Eksperimen & 75,0003 & 14,25881 \\
KJC & Mengukur & 65,6593 & 18,40831 \\
& Prediksi & 56,8681 & 30,06150 \\
& Hipotesis & 58,5165 & 25,33656 \\
& Eksperimen & 78,7544 & 14,24607 \\
KLE & Mengukur & 77,9760 & 19,57577 \\
& Prediksi & 51,6484 & 26,30014 \\
& Hipotesis & 54,6703 & 27,36383 \\
& Eksperimen & 76,4040 & 17,92702 \\
\hline
\end{tabular}

Tabel 2 menjelaskan jika secara umum indikator mengukur pada KPS dasar memiliki nilai rata-rata lebih 
Deskripsi keterampilan proses sains mahasiswa pendidikan fisika pada praktikum suhu dan kalor

menonjol daripada indikator prediksi, serta standar deviasi yang lebih kecil. Pada KPS terpadu indikator eskperimen mempunyai rata-rata yang lebih tinggi daripada indikator membuat hipotesis. Berikut hasil sebaran KPS dasar dan KPS terpadu pada materi suhu dan kalor kegiatan perubahan wujud dijabarkan pada tabel 3 .

Tabel 3. Sebaran Keterampilan Proses Sains Dasar dan Terpadu

\begin{tabular}{cccc}
\hline KPS & Indikator & Kategori & $\%$ \\
\hline Dasar & Mengukur & STB & 2,197 \\
& & TB & 10,989 \\
& & B & 37,363 \\
& & SB & 49,451 \\
& Prediksi & STB & 7,692 \\
& & TB & 12,088 \\
& & B & 21,978 \\
Terpadu & Hipotesis & SB & 58,242 \\
& & STB & 15,384 \\
& & TB & 32,967 \\
& & B & 28,571 \\
& Eksperimen & SB & 23,076 \\
& & STB & 1,098 \\
& & TB & 6,593 \\
& & B & 50,549 \\
& & SB & 41,758 \\
\hline
\end{tabular}

Berdasarkan tabel 3 diketahui bahwa KPS mahasiswa telah dapat dikuasi dengan baik ketika melaksanakan praktikum perubahan wujud. Hal ini menunjukkan, bahwa rata-rata penguasaan KPS dasar pada indikator yang diteliti telah terkategori sangat baik. Sejalan dengan hal itu, KPS terpadu telah terkategori baik. Prediksi merupakan indikator pada KPS dasar dengan presentase tertinggi yakni 58,242\%. Indikator melakukan eksperimen merupakan indikator KPS terpadu yang paling tinngi prasentase penguasaanya sebesar 50,549\%.

Tabel 4 menunjukkan sebaran keterampilan proses sains dasar dan terpadu pada praktikum suhu dan kalor kegiatan kalorimeter.

Tabel 4. Sebaran Keterampilan Proses Sains Dasar dan Terpadu

\begin{tabular}{llll}
\hline KPS & Indikator & Kategori & $\%$ \\
\hline Dasar & Mengukur & STB & 8,791 \\
& & TB & 26,373 \\
& & B & 42,857 \\
& Prediksi & SB & 21,978 \\
& & STB & 13,187 \\
& & TB & 30,769 \\
Terpadu & Hipotesis & SB & 30,789 \\
& & STB & 25,275 \\
& & TB & I0,989 \\
& & B & 37,363 \\
& & SB & 19,78 \\
& & STB & 3,296 \\
& & TB & 23,076 \\
& & B & 36,263 \\
& & SB & 37,362 \\
\hline
\end{tabular}

Berdasarkan tabel 4 diketahui bahwa penguasaan KPS dasar mahasiswa pada kegiatan praktikum kalorimeter dapat dikategorikan baik. Pengusaan tertinggi yaitu pada indikator mengukur dengan presentase 42,857\%. Sedangkan pada ketrampilan proses sains terpadu mahasiwa untuk indikator membuat hipotesis dapat diklasifikasikan tidak baik dengan presentase 37,363\%.

Tabel 5. Memperlihatkan sebaran keterampilan proses sains dasar dan terpadu pada kegiatan praktikum suhu dan kalor kegiatan kalor jenis cairan.

Tabel 5. Sebaran Keterampilan Proses Sains Dasar dan Terpadu

\begin{tabular}{cccc}
\hline KPS & Indikator & Kategori & $\%$ \\
\hline Dasar & Mengukur & STB & 3,296 \\
& & TB & 19,780 \\
& & B & 39,560 \\
& & SB & 37,362 \\
& Prediksi & STB & 38,461 \\
& & TB & 18,681 \\
Terpadu & & B & 19,780 \\
& & SB & 23,076 \\
& & STB & 26,374 \\
& & TB & 26,374 \\
& & B & 34,066 \\
& & SB & 13,187 \\
& & STB & 1,0989 \\
& & TB & 13,187 \\
& & B & 34,066 \\
& & SB & 51,648 \\
\hline
\end{tabular}

Tabel 5 menjelaskan bahwa rata-rata pengusaan KPS mahasiswa ketika praktikum kalor jenis cairan terkategori baik. Pada indikator KPS dasar pengusaan keterampilan mengukur dikategorikan baik dengan presentase $39,560 \%$. Untuk indikator KPS terpadu mahasiswa sangat baik pada indikator melakukan eksperimen sebesar $51,648 \%$.

Tabel 6 menjabarkan keterampilan proses sains mahasiswa pada kegiatan praktikum suhu dan kalor materi kegiatan kalor lebur es.

Tabel 6. Sebaran Keterampilan Proses Sains Dasar dan Terpadu

\begin{tabular}{cccc}
\hline KPS & Indikator & Kategori & $\%$ \\
\hline Dasar & Mengukur & STB & 6,593 \\
& & TB & 14,285 \\
& & B & 31,868 \\
& & SB & 47,252 \\
& Prediksi & STB & 37,362 \\
& & TB & 32,967 \\
& & B & 15,384 \\
Terpadu & Hipotesis & SB & 14,285 \\
& & STB & 36,261 \\
& & TB & 24,181 \\
& & B & 24,184 \\
& Eksperimen & SB & 15,374 \\
& & STB & 5,494 \\
& & TB & 16,483 \\
& & B & 38,461 \\
& & SB & 39,562 \\
\hline
\end{tabular}

Berdasarkan tabel 6 terlihat jika KPS dasar mahasiswa pada indikator prediksi terkategori sangat tidak terampil dalam menyampaikan prediksi dengan presentase 
$37,362 \%$. Begitu pula, pada indikator membuat hipotesis yang dapat diklasifikasikan sangat tidak baik sebesar $36,261 \%$. Pada indikator mengukur dan melakukan eksperimen mahasiswa dapat diklasifikasikan sangat baik dalam menguasai keterampilan tersebut.

\section{Pembahasan}

Keterampilan proses sains dasar wajib untuk dimiliki ketika proses penyelidikan ilmiah.. Mengukur merupakan kegiatan observasi sekaligus melakukan perhitungan terhadap alat ukur yang dipakai. Pengukuran adalah kegiatan yang mengharuskan untuk menggunakan alat ukur dan melakukan perhitungan untuk menentukan hasil pengukuran [20]. KPS dasar pada indikator mengukur secara umum telah terkategori baik dan telah dapat dikuasai mahasiswa. Pada kegiatan praktikum materi perubahan wujud dan kalor lebur es pengusaan mahasiswa terhadap katerampilan tersebut terkategorikan sangat baik dangan presentase berturut-turut sebesar 49,45I dan $47,252 \%$. Kegiatan praktikum kalorimeter dan kalor jenis cairan mahasiswa dapat dikatakan baik dengan presentase berturut-turut $42,857 \%$ dan 39,560\%.

Keterampilan proses sains dasar yang belum dikuasai dengan maksimal adalah membuat prediksi praktikum. Predicting is to anticipate the consequences of a new situation or change past experience and previous observations [2I]. Pada indikator ini, kegiatan praktikum materi perubahan wujud dan kalorimeter terlihat jika mahasiswa telah dapat menguasinya dengan presentase $58,242 \%$ dan 30,789\%. Sedangkan ketika kegitan praktikum kalor jenis cairan dan kalor lebur es mahasiswa terkategori sangat tidak baik 38,461\% dan 37,362\%. Kegiatan membuat prediksi dilakukan saat mahasiswa belum melakukan kegiatan praktikum sehingga mahasiswa terkadang merasa sedikit bingung untuk membuat kesimpulan awal percobaan. Dari wawancara yang dilakukan diperoleh informasi bahwa mahasiswa belum dapat memahami secara sepenuhnya variabel dalam praktikum ataupun hukum yang berkaitan dalam percobaan.

Indikator selanjutnya yang diteliti, yaitu membuat hipotesis, menurut [22], hipotesis merupakan suatu pernyataan yang berdasarkan asumsi dan belum terbukti kebenarannya, biasanya hipotesis digunakan dalam menentukan teori dan hukum. Jadi, hipotesis merupakan asumsi awal didasarkan rancangan percobaan, kemudian dapat membantu merumuskan suatu teori. Berdasarkan penelitian yang dilakukan indikator membuat hipotesis pada praktikum kegiatan perubahan wujud dan kalorimeter terkategori tidak baik sebesar 32,967\% dan $37,363 \%$. Sedangkan pada praktikum kelor jenis cairan mahasiswa telah mulai menguasai keterampilan ini dengan baik yaitu persentasenya sebesar 34,066\% dan untuk kegiatan kalor lebur es indikator ini tidak dikuasai secara baik oleh mahasiswa presentasenya yaitu 36,261\%. Kebanyakan mahasiswa ketika merumuskan hipotesis masih disamakan dengan membuat prediksi.

Indikator terakhir yaitu melakukan eksperimen, menurut Ref. [8] menyatakan bahwa, eksperimen termasuk menggunakan bahan yang dibutuhkan untuk membuat mekanisme sesuai tujuan praktikum, perubahan dan variabel kontrol untuk mencapai data, mancatat dan menevaluasi data untuk menganalisisnya, menarik kesimpulan dan memberikan laporan terhadap percobaan yang dilakukan. Dapat dikategorikan bahwa indikator melakukan eksperimen telah dikuasai mahasiswa dengan baik bahkan sangat baik presentasenya berturut-turut yaitu 50,549\%, 37,362\%, 51,648\%, 39,562\%. Dari hasil wawancara, didapatkan informasi bila mahasiswa telah dapat menguasai indikator ini dengan baik dikerenakan ketika melakukan percobaan maka mahasiswa hanya mengikuti prosedur. KPS baik untuk ditumbukan dalam diri mahasiswa karena dapat meningkatkan literasi sains dan membuat mahasiswa melek sains. KPS membantu individu untuk melek terhadap sains [23]. Selain hal tersebut dengan mempunyai KPS maka individu dapat memilliki keterampilan untuk memecahkan masalah sehari-hari [24].

\section{Kesimpulan}

Berdasarkan hasil deskripsi yang dilakukan dengan melihat besar presentase sebaran KPS mahasiswa pada percobaan perubahan wujud, kalorimeter, kalor jenis cairan, dan kalor lebur es maka indikator yang telah baik dikuasai mahasiswa yaitu melakukan pengukuran dan melakukan eksperimen. Dua indikator berikutnya yaitu memprediksi dan membuat hipotesis mahasiswa belum dapat memaksimalkan kemampuannya dalam menguasai keterampilan ini. Saran untuk memaksimalkan penguasaan indikator membuat prediksi dan hipotesis mahasiswa dituntut untuk banyak berlatih memahami cara merumuskan kesimpulan awal dan membuat suatu hipotesis. Dengan maksimalkan keterampilan proses sains yang dimiliki oleh mahasiswa dapat membantu dalam mengembangkan serta meningkatkan pengetahuan mahasiswa melalui suatu kegiatan praktikum.

\section{Kepustakaan}

[I] Azizah. K. N, Ibrahim. M, \&Widodo. W, Process Skil Assessment Instrument: Innovation to measure student's learning result holistically, Journal of Physics: Conference Series, vol. 947, no. I, 2018 p. 012026.

[2] Karamustafaoğlu. S, Improving the science process skills ability of prospective science teachers using I diagrams, Eurasian Journal of Physics and Chemistry Education, vol. 3, no. I, 20II, pp. 26-38.

[3] Gultepe. N, High School Science Teachers' Views on Science Process Skills, International Journal of Environmental and Science Education, vol. II, no. 5, 2016, pp. 779-800. 
Deskripsi keterampilan proses sains mahasiswa pendidikan fisika pada praktikum suhu dan kalor

[4] Fadlan. A, Strategi Peningkatan Keterampilan Calon Guru Dalam Menerapkan Pembelajaran Aktif Melalui Mei (Modelling, Engaging, And Integrating)(Strategy in Improving Prospective Teachersâ $€^{\mathrm{TM}}$ Skills in Implementing Active Learning through MEI (Modelling, Engaging, an, Jurnal Kreatif) Jurnal Kependidikan Dasar, vol. I, no. I, 2010.

[5] Wardani. S, Pengembangan keterampilan proses sains dalam pembelajaran kromatografi lapis tipis melalui praktikum skala mikro, Jutnal Inovasi Pendidikan Kimia, vol. 2, no. 2, 2008, pp. 317-322.

[6] Ergül. R, Şımşeklı. Y, Çaliş. S, Özdılek. Z, Göçmençelebı. Ş, \& Şanli. M, The Effects Of Inquiry-Based Science Teaching On Elementary School Students'science Process Skills And Science Attitudes, Bulgarian Journal of Science \& Education Policy, vol. 5, no. I, 20II, pp. 48-68.

[7] Rezba. R. J, Sprague. C. S, Fiel. R.L, Funk. H. J, Okey. J. R, \& Jaus, H. H, Learning and assessing science process skills (3rd Ed.), Dubuque, IA: Kendall/HuntPublishing Company, 1995.

[8] Ergin. O, Sahin-Pekmez. E, \& Ongel-Erdal. S, Kuramdan uygulamaya deney yoluyla fen ögretimi (Science teaching through experiment from theory to practice), Izmir: Dinazor kitapevi, 2005

[9] Aydogdu. B, The investigation of science process skills of science teachers in terms of some variables, Educational Research and Reviews, vol. I0 no. 5, 2015, pp. 582.

[10] Hafez. Z. A, \& Rashed. J. M, Science Process Skills and Attitudes Toward Science Among Palestinian Seconary School Students, Journal of education, vol. 2, no. 5, 2015, pp. 13-24.

[II] Mutisya. S. M, Rotich. S, \& Rotich. P. K, Conceptual understanding of science process skills and gender stereotyping: a critical component for inquiry teaching of science in Kenya's primary schools, Asian Journal Of Social Sciences \& Humanities, vol. 2, no. 3, 2013, pp. 359-369.

[12] Downing. J. E, \& Gifford. V, An investigation of preservice teachers' science process skills and questioning strategies used during a demonstration science discovery lesson, Journal of Elementary Science Education, vol. 8, no. I, 1996, pp. 64.

[13] Çepni. S, \&Çil. E, A case study for reliability on portfolio evaluation, Procedia-Social and Behavioral Sciences, vol. I no. I, 2009, pp. 963-968.

[14] Anderson. R . D, Reforming Science Teaching: What Research Says About Inquiry, Journal of Science Teacher Education, vol. I3, no.I, 2002, pp. I-I2.

[15] Ary. D , Jacobs. L. C, Irvine. C. K. S, \& Walker. D, Introduction to research in education, Cengage Learning, 2018.

[16] Sugiyono, Metode Penelitian: Kuantitatif, Kuanlitatif, dan $R \& D$, Bandung, Alfabeta, 2007.

[17] Hindarto. N, \& Edie. S. S, Analisis Kebiasaan Bekerja Ilmiah Mahasiswa Fisika Pada Pembelajaran Mata Kuliah Praktikum Fisika Dasar, UPEJ Unnes Physics Education Journal, vol. 2, no. I, 2013, pp. 85-9I.

[18] Rauf. R. A. A, Rasul. M. S, Mansor. A. N, Othman. Z, \& Lyndon. N, Inculcation of science process skills in a science classroom, Asian Social Science, vol. 9, no. 8, 2013, pp. 47-57.

[19] Wiwin. E, \& Kustijono. R, The Use Of Physics Practicum to Train Science Process Skills And Its Effect on Scientific Attitude of Vocational High School Students, Journal of Physics: Conference Series, vol. 997, no. I, 2018, pp. I-8.

[20] Dogan. I., \& Kunt. H, Determination of Prospective Preschool Teachers' Science Process Skills, Journal Of European Education, vol. 6 no. I, 2017, pp. 8-I8.

[2I] Espinosa. A. A, Monterola. S. L. C, \& Punzalan. A. E, Careeroriented performance tasks in chemistry: Effects on students' integrated science process skills, Cypriot Journal of Educational Sciences, vol. 8, no. 2, 2013, pp. 2II-226.

[22] Kazeni. M.M.M, Development and validation ofa test integrated science process skills for the further Education and 